\title{
NOTES ON THE HIGH-LEVEL RIVER DRIFT BETWEEN HANWELL AND IVER.*
}

BY T. ALLEN BROWN, F.G.S.

(Read 3rd May, r895.)

THE high-level river drift deposits between Hanwell (Middlesex) and Iver (Bucks) have been chosen as the subject of this paper because the exposures in that district present features of great interest and importance. These deposits have been under careful investigation by me for many years as fresh sections have been exposed, and from my voluminous notes thereon, I have selected for the purpose of this paper such as may serve to indicate the general character of these high-level drifts, their probable origin and formation.

The evidence which will be brought forward will show that some, at least, of the deposits under review, are not the result of simple fluviatile agency, as has been generally supposed, but that large accumulations of ice-borne material seem to bave actually formed at the time the river flowed at levels from above I $80 \mathrm{ft}$. O.D. down to below the 75 -foot contour in the districts under investigation.

Further than this, it will be suggested that vast masses of frozen gravel, sands, and clay were carried bodily into the stream itself, where they remain until to-day to tell their story. To such deposits (the result of combined river-and ice-action) it is proposed to apply the term Fluvio-Glacial. In proposing this term for the very high-level drifts, it should be understood that the word glacial is employed in a local sense, and signifying, as Mr. Whitaker says, "the occurrence of very cold or icy conditions."

I would include in the Fluvio-Glacial deposits, as will be seen in the description of the sections, some of the deposits now described on the drift maps as "Glacial." It is difficult to distinguish them either in structure or composition from some forms of drift hitherto considered as fluviatile. They occur, among other places, west of Uxbridge and Hillingdon, and west of the Colne Valley, and are only separated from known river drift by narrow patches of lower Tertiary, from which the drift has been denuded.

It will be snown that these so-called glacial deposits are found, like the river drift, descending the slope of the hills from the higher ground to the north in Middlesex and Bucks to the same level as, or even to a lower contour than, the known river drift at Uxbridge Common, Hillingdon, etc. Alluding to these drifts, Mr. Whitaker has said: "The glacial drift may contain beds

* This paper was read with special reference to the Excursion of $4^{\text {th }} \mathrm{May}, 1895$, for report of which see ante, Proc. Geol. Assoc., vol. xiv, p. 118.-Ev.

August, i $895 \cdot]$ 
which are not of distinctly glacial origin; but there seems to be no need of using a special word for such and calling them Interglacial. They are part and parcel of the formation-mere interludes as it were-showing only some temporary or local changes."**

Palæolithic implements have been found throughout the whole district under investigation, generally in the stratified beds, but also much abraded specimens in in-filled furrows, showing that man existed in this neighhourhood from the earliest period which the beds record, even when the stream flowed over and eroded the London Clay. A few specimens in my collection are of the peaked and other plateau types, discovered by Mr. B. Harrison on the Chalk escarpment in Kent, and described by Professor Prestwich. $\uparrow$

In others, the angles of fracture are almost obliterated by abrasion, and the surfaces partly decomposed by the action probably of humic acid or other solvent. These rude and halfobliterated implements seem to have been, in many cases, swept off the ground by the same agency which removed the gravel, clay, and sand from the surface and deposited it at lower levels. Some of these specimens have been found at the high level of I 80 O.D.

I now propose to describe sections of Drift in the localities hereinafter mentioned.

\section{HaNWEIL.}

A little north of the large iron bridge which crosses the Uxbridge Road at Hanwell, and a short distance south-east of the "Mill ponds," there is a gravel pit, which, for many months past, has presented a very remarkable illustration in conformation of the foregoing remarks (see Fig. 1). In the section lately shown the depth of the excavation was over 20 feet, the base of the drift not being seen. At the base of the section is a horizontally stratified bed of gravel and sharp sand, of which a thickness of 7 or 8 feet is exposed.

Reaching from the bottom of the brick earth and trail to beyond the lowest part of the face of the excavation, is an irregular furrow or depression, from 16 to $\mathrm{i} 8$ feet wide at the top, or widest part, and varying from I I to $\mathbf{I} 2$ feet in depth. It penetrates deeply into the stratified bed, which is disturbed and contorted on both sides of the furrow, being, in fact, in some places, bent beneath, and, at the sides, following the form of the funnelshaped deposit. In the centre of the channel, near the top, is a large irregular patch or included deposit of blue silty clay and bleached pebbly gravel, in striking contrast to the yellow and ochreous gravel which encloses it. There are also, in other 


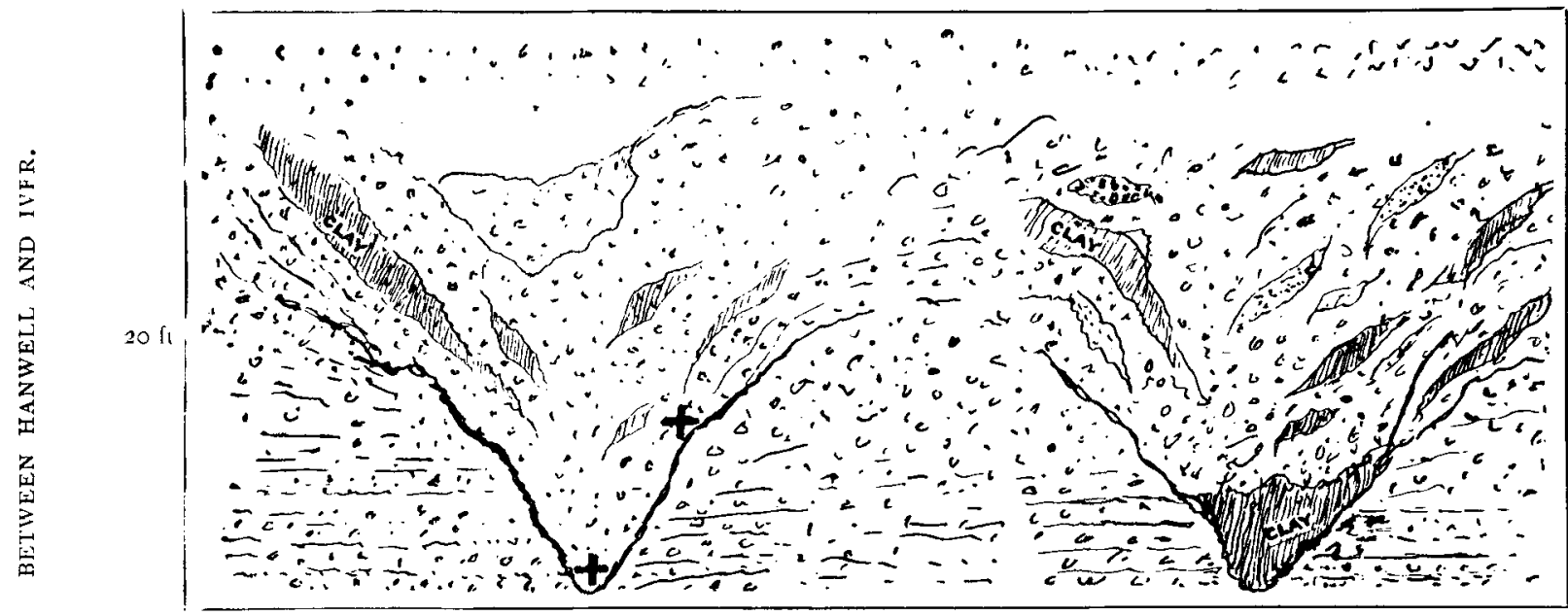

About $60 \mathrm{ft}$.

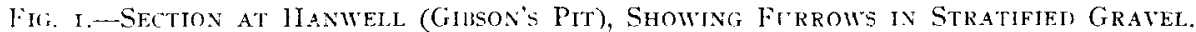
+ Implements found here. 
parts of the depression, irregularly formed deposits of the same blue clay, sand, and whitened pebbles, and sub-angular gravel, with ochreous gravel in other places, thus filling the furrow-this furrow had been almost cut away by the pitmen when the members visited the pit on the $4^{\text {th }}$ May, but a similar furrow was then seen close to it. Above the irregular, and, apparently, eroded top of the filled-in furrow, is a mottled sandy clay, or brick earth (not the usual brown stiff clay most frequently met with), 4 or 5 feet thick, surmounted by a scattered deposit of clayey gravel (trail).

This wide, deep furrow, or channel, has been traced by me for $15^{\circ}$ feet, but it probably exceeded that amount in length. The gravel deposits in this locality do not extend far to the north, though they can be traced up to the higher ground to the N.E., on which Hanwell Church is built.

There can be no doubt that the drift must, from the position of the deposit, have once extended to the north, where is now the Brent Valley, but it has been denuded, and erosion has taken place in the London Clay beneath.

The gravel in the furrows is of a different character from the stratified beds in which numerous "erratics" are found, and I found its composition to be as follows:-

Pebbles, including seven or eight black ones, probably derived from the Eocene . . $\quad 78$

Fragments of white crusted Flint nodules abraded 3

Small Quartzite Pebble . . . . . I

Sub-angular Flints, some bleached . . . I4

Small Ragstone Pebble . . . . . I

Small Quartz Pebbles from the size of a small pea

to a small marble . . . . . . 3

$$
\frac{3}{100}
$$

This analysis may be taken as a fair representation of the contents of many other furrows, and it contrasts with that of the stratified bed which contains purple and yellow quartzites, quartz, etc., in the form of small boulders, and, very rarely, flints with a bleached surface.

Several other furrows have been exposed in this pit, and the spaces which divided them above the stratified bed were composed of confused masses of unstratified ochreous and bleached gravel with included deposits of blue and brown clay and sand. Between the two furrows mentioned the deposits were squeezed up into archlike forms. The whole deposit has the appearance of having been torn or swept from the surface of the land to the north

A large coarsely-worked flint implement formed from a large flake much abraded was discovered at the bottom of the furrow; 
it is striated with intersecting lines in the same way as stones found in the Boulder Clay on the more flattened face, and the surface of the implement, which is of the peculiar curved form found in the oldest beds, is partially decomposed by age and weathering. A smaller flat pear-shaped implement, also abraded and slightly eroded into small pittings on the surface, was found just inside the furrow, and also a small flake. There can hardly be a doubt that both implements must have been transported to lower ground by the same agency which formed and removed the other contents of the channel. If my observations and

Surface Soil.

W. Surface Soil.

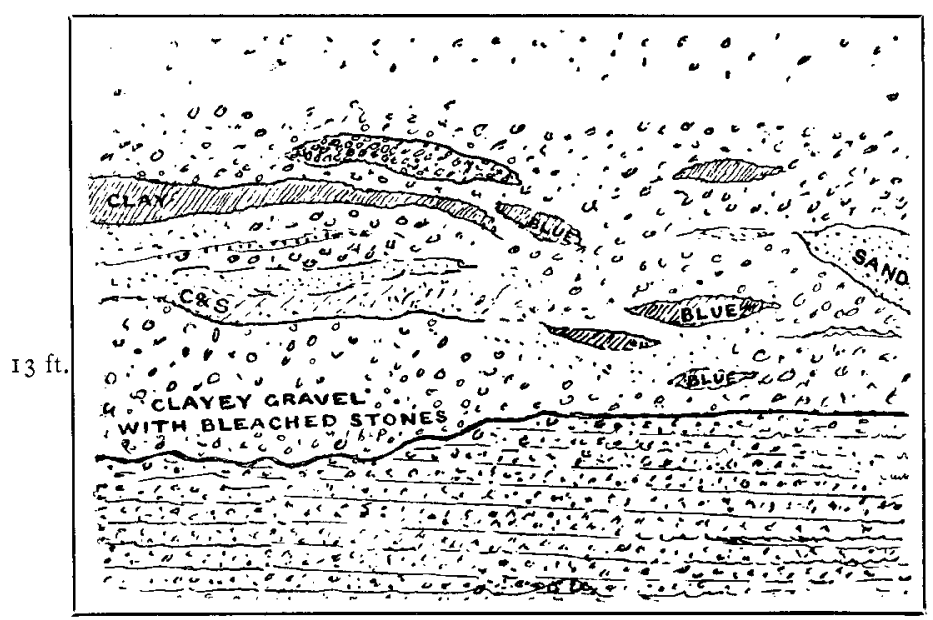

About $25 \mathrm{ft}$.

Fig. 2.-Section at Haxwell (Macklin's Pit), Showing Eroinei) Stratifiei) Gravel Beneath Unstratified Drift, With ENClisurej of Blete and Brown Clay, Sani, Bezached Pebibles, ETC.

deductions are accepted, how can man, whether he was contemporary with the Chalky Boulder Clay or not, be considered Post-Glacial in this neighbourhood? A few flint implements have also been found in the underlying stratified beds in this pit.

A particularly good example of the thick deposit of contorted unstratified drift above stratified beds has been often seen by me at Macklin's pit, Maunders Road, near the High Street, Hanwell, about a mile eastward of the excavation just described, and at rather under the roo foot contour (see Fig. 2). The tace of the excavation was rather more than 2 feet in depth, and the unstratified deposit and brick-earth above it occupied two-thirds of the upper part of the section; in some parts of this very extensive excavation 
the stratified bed beneath was very distinctly eroded, the line of demarkation between the upper and lower deposits being very irregular and clearly shown. This erosion of the lower bed is often noticeable at Ealing and other districts, a remarkable instance being seen on the slope of Castlebar Hill, Ealing, at about I 25 to I 30 O.D., and a very early type of flint implement was discovered there. As the work was being done during the last three years at Hanwell several furrows, filled with different kinds of gravel, clay, and sand, were noticed. In a section of this pit, drawn in $\mathbf{1} 892$, I saw, in unstratified gravel with enclosures of sharp green sand and bluish and brown clay, a large tabular, water-worn Tertiary Sarsen which two men could lift with difficulty, and eight feet to the north of the place where it was discovered another large piece, not quite so heavy, was met with-they had formed parts of the same block, which had been broken in Quaternary times, as shown by the old surfaces of fracture, and they fitted together. I had them conveyed to my garden, and they are now placed by the drive for the inspection of geologists.

Another large boulder of Sarsen was seen by me, in 1889 , in a pit at the back of Hanwell Station; it was protruding from the base of the generally unstratified sandy and, in parts, clayey gravel. I measured the exposed portion, which was $3 \mathrm{ft}$. 7 in. in length, $2 \mathrm{ft}$. gin. at the widest part, and nearly $\mathrm{I} \frac{1}{2} \mathrm{ft}$. in thickness; it was lying in fine gravel, with the coarser, contorted gravel, etc., above it; there was an appearance of cross-bedding on both sides of it, produced, no dcubt, by the melting of the ice which cemented the material together into a frozen mass : at least eight feet of drift was above the Sarsen. Implements and flakes have been found in the river drift beneath it.

\section{SOUTHALL.}

Passing now to Southall, it should be noted that some large excavations have been made there during the past three or four years for gas-holders; they were deeper than is usually the case where pits are made to obtain gravel; the uneven surface of the London clay was reached at rather more than 25 feet; the same irregular structure of the upper part of the face of the excavations was generally noticeable, though there were occasional sections seen in which there was an appearance of stratificationno more, however, than frozen masses of gravel and sand would produce on the melting of the ice which bound them together.

Several teeth and the bones of Elephas primigenius were found in these excavations, which are at about the roo foot contour, and about two and a half to three miles N.IV. of the spot where remains of the hairy Elephant and other bones were 
discovered associated with flint implements, I 3 feet from the surface at Norwood Lane, and described by me.*

Among the implements found in these excavations was an implement of quartzite, very much abraded, $6 \frac{1}{2}$ inches in length, it is coarsely chipped and of pointed type, and has been formed from a boulder, a portion of the surface of which is left at the butt for convenient use in the hand. It must be exceedingly old from its appearance and from the position in which it was found-i.e., very close to the London clay. Implements of quartzite are rare; only six or eight have, I believe, been discovered (two of which are in the collection of Sir John Evans and Mr. Llewellyn Treacher has others). A very large ochreous flint implement, $8 \frac{1}{2}$ inches in length, battered almost all over by contact with other stones, found $\mathbf{2 2}$ feet from surface, also rewarded the search of the pitmen; both of these are in my collection.

\section{Dawley and Hayes.}

The river drift is found up to the 127 contour, at the latter extending N.W. as a large sheet to the north of Hillingdon, as shown in Mr. Whitaker's elaborate memoir.

At Dawley there are very large excavations for procuring gravel and my notes thereon are numerous; it may be sufficient to say, that I have noticed in the sections, similar irregular unstratified deposits above stratified beds and also not unfrequently similar in-filled furrows, with enclosures of clay, etc., to those already described. Large quartzite and other erratic boulders are found abundantly in the lower beds, and but very rarely in the deposits above tnem ; on one occasion I carefully examined about io feet of the upper part of the face in length, and did not find one "foreign" rock except very small pebbles of quartz. Some years ago a number of large flint nodules as fresh as if they had just been taken from the chalk, were found near together in the unstratified gravel; some of them measured a foot in diameter, they were in a deposit of fine gravel included in the upper part of the section.

At the excursion of the Association on the 4th May, a fine long section of unstratified deposits above bedded dritt was seen extending along the northern face of the excavations in $\mathrm{Mr}$. Maynard's pit.

Among the many flint implements which have been found in the pits at Dawley, there are some which should be specially mentioned, foremost among which is one of a flattened pear-shape, about $4^{\frac{1}{2}}$ by $3^{\frac{1}{2}}$ inches of Felsite or Eurite with black spots of Riebeckite, a variety of Hornblende : the rock was kindly determined for me by Mr. Lazarus Fletcher, Keeper of the mineralogical

\footnotetext{
* Proc. Geol. Assoc. vol. x, p. $36 \mathrm{I}$.
} 
collections at the Museum of Natural History ; he tells me it is very like the material of some pebbles found in Wales. It is of flattened pear shape, and chipped all over.

It is, I believe, the first implement of Felsite which has ever been found in the river drift, and why a small boulder of this rock (so rare in the drift) from which it has no doubt been formed, should have attracted the eye of Palæolithic Man, it would be hard to say. It is in my collection with others from the same pits, which are of unusual interest. One is an almost unabraded flint implement nearly unique as to its perfect form and preservation; it is $7 \frac{1}{2}$ inches in length by $5^{\frac{1}{4}}$ wide at the butt, which is worked, and is also of a flattened pear shape, and has a lustrous brown surface; the implement was discovered, with several others of less importance, in a thin bed of laminated clay, intercalated with gravel and black carbonated matter in the stratified bed about 19 to 20 feet from the surface, and near it was a large flint nodule, which the men described as like an anvil. Another is a large oval flint instrument, chipped at each end into a double bladed axe, which is remarkable as clearly showing that it was hafted with a withe or branch, bent twice round it: there are two carefully chipped depressions on one side and one on the other for the reception of the withe after the Australian method. This and many others were found during a number of years in the stratified bed, 15 to 16 feet from the surface, as were also some flakes scratched or striated on the flat side. Three well-preserved casts of Rhynihonella (octoplicata?), probably from the Lias, were discovered close together in this pit.

At a short distance west of Maynard's gravel pits at Dawley is Pipkin's pit (Fig. 3), which, though it is not now worked, still shows very strong evidence of the passage from the north of large masses of frozen gravel and clay, as well as chalky débris, in Palæolithic times.

In a measured section of about 120 feet out of about 200 feet in length seen, and about i 3 feet in depth, a sketch of which with some photos was exhibited, I found, at the top, a dense brown clay or brick-earth with trail, beneath which was a very irregular deposit of chalk, rubble race, and clay, with a few stones in it, extending in tongue-like and wave-like forms into the clay -it was distinctly separated from the well-defined surface of partly stratified, and in other parts unstratified, deposits beneath containing quartz, quartzite and other erratic boulders, along the length measured, when it became mixed up and confused with contorted and lenticular deposits or enclosures of sharp sand and gravel-the underlying gravel, clayey at the upper part and very sandy lower down. The excavation did not reach, except in one place, to the regularly stratified bed, and the base of the drift was not seen. There can be no doubt whatever that the brown brick-earth had never been disturbed in recent times (specimens 


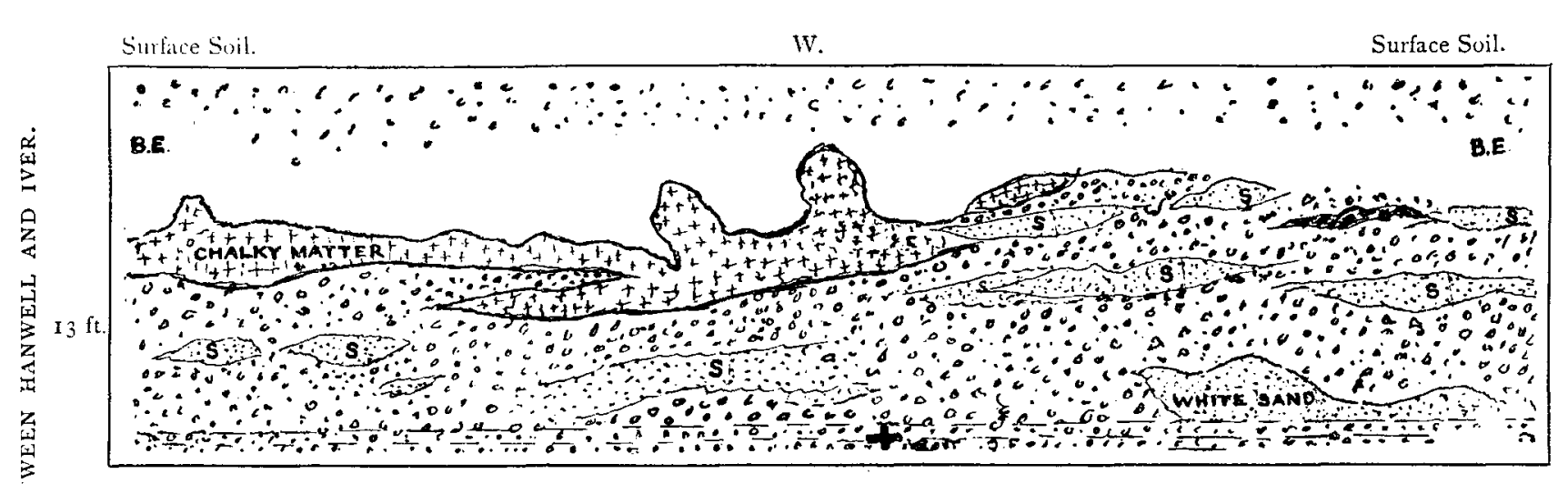

About $40 \mathrm{ft}$.

Fig. 3.-Section at West Draiton (Pipkin's Pit), Showing Chalky Matter and Gravel, with Enclosures of SAND, ETC.

$+A$ pointed implement found here. 
of the chalky rubble deposit were exhibited). It extends in several places to the eastern side of the pit. At the northern side, the more stratified gravel at the base is disturbed, and above it in other parts of the excavation the deposits of gravel are remarkably irregular and contorted, and contain long enclosures of sharp sand, and others of angular gravel and clay. A very perfect, yellow stained, pointed implement (now in my collection), was discovered about I 3 feet from the surface, in fine sandy gravel, beneath the disordered and confused deposits above. I visited the pit soon after it was found and carefully noted the site of the find. It seems impossible to doubt that the owner of that implement lived before or during the time these deposits were formed. Nor does there appear to be any other explanation than that the confused unstratified deposits above, with their contained chalk rubble and clay, etc., were the result of the intrusion of masses of frozen material, or a minor form of morainic deposit brought by ice from higher ground, it may be, at successive periods, into the bed of the old river represented by the lower or stratified deposits beneath, indicating very cold climatic conditions in winter, and a short warm summer, when the ice which cemented such varied deposits together melted, leaving most of the masses as we find them, but sometimes allowing of their being broken up and dispersed by the flowing river. The eroded surface of the lower bed would lead to the inference that it was, for a time at least, above water, and, probably, inhabited by man, until it was again invaded by ice-borne matter or Fluvio-Glacial Drift.

\section{West Drayton.}

Near the northern banks of the canal in this district there are large and very deep excavations for gravel, they are more than 9 miles from the nearest bank of the Thames (those at Dawley $7 \frac{1}{2}$ miles), and their level is about I10 to 116 o.D. The sections show the same deposits of generally unstratified and contorted gravel, with enclosures of sand, very pebbly gravel, bluish and brown clay, as described in the other localities mentioned, above a stratified bed, and beneath brick-earth and trail (see Fig. 4). Occasionally the bedded gravel reaches a higher level in the sections in these pits, as if it had not been invaded to the same extent by ice-borne frozen matter. Many of the large number of flint implements found in the pits at West Drayton, as well as at Dawley, are very much abraded, and, in many cases, the angles of chipping are half obliterated. There are many others, however, in my collection from these large excavations, which have not suffered at all from rolling, while others are slightly abraded. Among the former is a large, yellow-stained, pointed, flint implement, 9 inches in length, with heavy butt, found at I4 feet from the surface. A very noticeable feature in this specimen is that it again gives us an insight into the method by which 
such a large instrument was hafted, as it is much too large for use in the hand alone. Towards the butt end is a natural hollow in the crust of the nodule from which it was formed, and, corresponding to it, on the other side, is a well worked chipped depression. A design so apparent, as also seems the case of the large axe from Dawley already described, furnishes almost as positive evidence that it was used as a large pointed axe, hafted with a bent branch, as if the withe had been found with it. A very fine pointed specimen, nearly 6 inches long, with ochreous patina, may be mentioned. It was discovered ${ }_{5} 5$ feet down, with many other sharply-pointed implements, unabraded, at about the same level.

Surface Soil.

E.

Surface Soil.

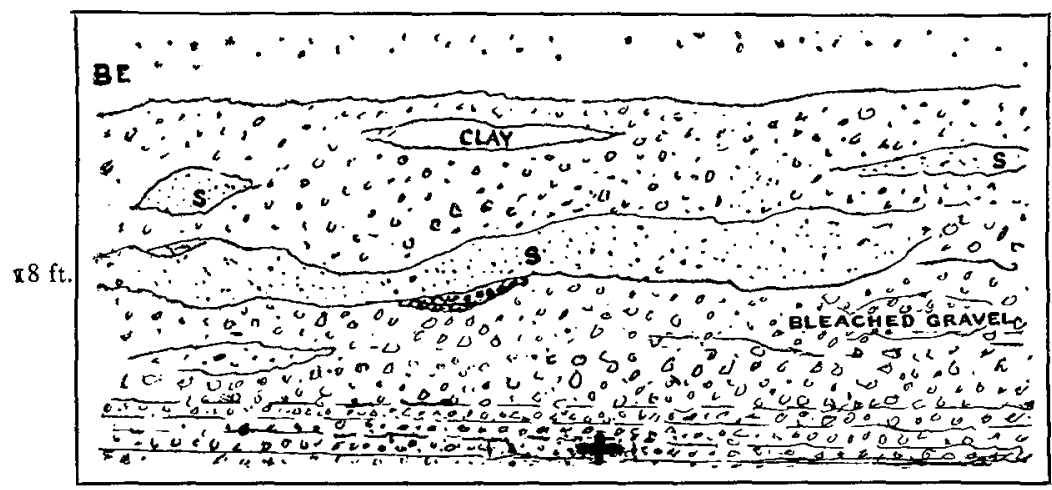

About $25 \mathrm{ft}$.

Fig. 4.-Section at West Drayton (Eastwood's Pit), Showing Stratified bineath Unstratified Drift.

B.E. Brick-earth

+ Implements found here.

A full description of the implements found in these pits would take up more space than is at my disposal, but mention should be made of a large, very rude, ochreous implement, $6 \frac{1}{2}$ inches in length, formed from a coarse flake, which, like others in my collection, is very distinctly striated : the striations intersect each other and extend over the entire surface.

A number of Palæolithic implements of later age, consisting of long, sharp spear-heads, knives, etc., wrought into shape by secondary chipping, have been discovered nearer the surface than the ordinary implements formed from nodules. They are generally found at depths varying from 5 to ro feet, and beneath the unstratified deposit. They are often nearly 6 inches in length, and are as sharp and unabraded as if they were made yesterday; they vary in colour externally and are lustrous. 
As mentioned elsewhere, they probably belong to the same age as those found at the late Palæolithic workshop floor at Acton, which they greatly resemble, and may be classed with the long, flake-formed implements of the oldest cave in the Dordogne, that of Le Moustier. They are found beneath the unstratified deposit and the brick-earths, and the different depths at which they are discovered may be accounted for in the varying thickness of the unstratified or ice-borne deposit, and its absence in some sections, or the stratified beds may not have suffered so much from erosion.

The discovery of the flake-formed implements, so like the surface specimens, in different places, high up in sections, in the Thames Valley, besides the original find at Acton, is of great significance with other facts as showing the continuity of man's existence in the Valley, as I have elsewhere shown.*

\section{UXBRIDGE AND HILLINGDON.}

Northwards from West Drayton and Dawley there is a large spread of gravel and brick-earth entirely above the roo foot contour, extending up to Harefield Lodge to the north, stretching out south-east to beyond Hayes ( 127 O.D.), where it is met by a large deposit of brick-earth (shown on the drift map), underlying which no doubt gravel will be found, and continuing farther east, with an irregular margin and tongues of river drift, to a lower level. On the west it extends to Denham and on the south-west to beyond Iver (Bucks). This wide extension of river drift northward to Harefield Lodge, and probably beyond, is of the highest importance in its relation to the so-called Glacial Drifts west and north of it. These deposits are intersected by the streams collectively called the Colne.

The river drifts reach the high level of about I86 O.D. at Uxbridge Common, south of which they are divided, by a narrow tract of eroded London clay, from the larger mass to be seen in the Parish gravel pits a short distance south-east of Hillingdon Church at about 177 O.D. Mr. Whitaker has so accurately yet briefly described these high-level river drifts, that it is well to quote the words in his elaborate memoir. $\dagger$ He says: "A. spur of gravel spreads over Uxbridge Common northward to Harefield Lodge, and forms the top of the hill. This high terrace may perhaps be an outlier, separated on the south by erosion through the underlying London clay on the higher part of Uxbridge, along a line parallel to, but a little above, the High Street; the gravel has been worn away along the valley between Uxbridge and Hillingdon, to a point a little south of the road; but it again spreads northward over the higher ground to Little

* "The continuity of the Palæolithic and Neolithic Periods." Iourn. Anthrop. Inst., Aug. and Nov., 1892 .

+ Geology of London, 1889 , vol. i, p. 393. 
Hillingdon, and thence south-eastward to the brook at Yedding Green, the boundary line gradually falling to a lower level. The rectangular area of brick-earth between the last place, West End, and the canal, has a doubtful boundary. On the other side of the canal, the London clay rises from beneath; but further east a spur of gravel rises northward to Greenford, and is cut off on the east of the Brent, which river has worn its way through the London clay as far south as Hanwell, if not farther. Around Hillingdon and Hayes there is gravel, south of Uxbridge there is brick-earth as well, and at West Drayton and thence to Southall, there is a large sheet of the latter." At first sight it might appear that the high-level river drifts at Uxbridge Common, Hillingdon, and southward, may have had some relation in the past to the Colne, which flows through them, in the same sense as the Thames may be considered as the lingering relic of the larger river of Quaternary times which deposited the high-level river drift; but this suggestion does not appear to be tenable upon closer investigation, because the gravel which forms the top of the hill at Harefield Lodge, Uxbridge Common, and Hillingdon is found covering the slope of the hill to the east and west. It descends, as we have seen, from about I 80 0.D. to I 27 O.D. at Hayesand to a lower contour still further east. On the west of the Colne the same gravel is found descending the hill on that side above the 145 contour north of Denham and extending south, but divided by London clay, the result of erosion, and by patches marked "Glacial" in the drift map, from the river drift in the district of Iver.

A few other facts connected with this high-level river drift and its relation to Glacial drift may be of interest. Going north from Harefield Lodge to the village of Harefield, the Glacial deposits appear at about the 290 th contour, and they are also seen to the north and north east as well as north-west of Rickmansworth ; in all instances they follow the slopes of the hills. It is a remarkable fact that the area west of the Colne marked on the map "Glacial," to which I have before alluded, descends to a lower level than the river drift at Uxbridge and Hillingdon, as it falls from 200 O.D. at Dromena to 156 at Love Green.

It is difficult, too, to detect any difference between the two forms of deposit either in their structure or in their constituents.

There are no sections exposed to the east of Uxbridge Common, but on the ploughed land there is abundant evidence ot the character of the river drift in that locality. Some flakes, apparently from their patina Palæolithic, were found by me there; but the most remarkable feature of this gravel is the larger proportion of erratics it contains, of which a close grained diorite is most abundant, but I could find no oolitic or Oxford clay specimens. At Hillingdon, a short distance S.E. of the church, at about 177 o.D., there are extensive pits, showing, in the sections 
I sketched some years ago, about $I \frac{1}{2} f \in e$ et of brick-earth with a thin seam of red gravel through it, underlying which was a confused deposit of very reddish ochreous, sub-angular flint and pebbly gravel, with slight, if any, stratification; it contains black matter and small enclosures of greyish green sand, beneath which, and divided by a horizontal black seam, is an ochreous gravel formed of larger stones with sharp sand, which appears to be horizontally bedded. In the latter, which contains many small boulders of quartz, quartzite (both the light and the purple variety), granite, and other erratics, have been discovered several fint implements, some of which are in my collection. These implements, therefore, come from the highest level at which such human relics have been found in Middlesex.

West of the road passing over Uxbridge Common there was a small excavation which was visited by me in 1893 . The section

Surface Soil. N. Surface Soil.

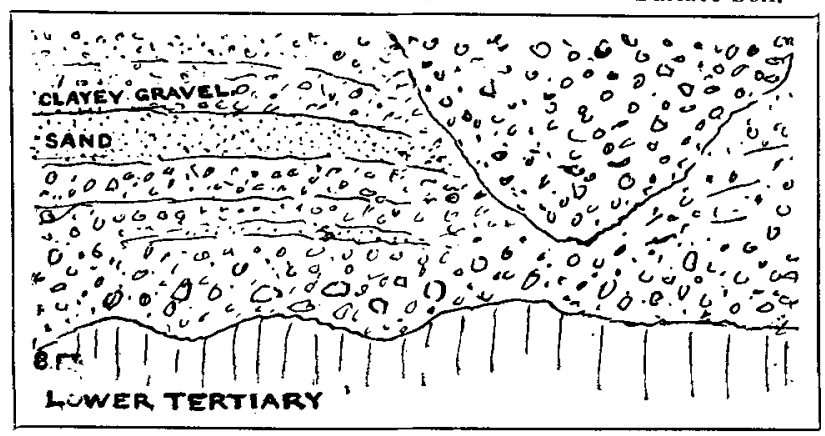

Fig. 5.-Section West of UxBRIDGe Common.

(Fig. 5), drawn at the time, shows at the northern face of the pit about 8 to 9 feet of nearly horizontally bedded ochreous gravel with clayey sand at the top, beneath which was fine gravel containing flint nodules slightly abraded and small boulders of quartzite (purple and light jellow), quartz, etc. (particularly at the base), resting on the very uneven eroded lower Tertiary bed. The most remarkable feature of the section, however, was a deep furrow filled with unstratified clayey gravel, in part sub-angular, but largely composed of pebbles, many of them black. from the lower Tertiary. The furrow was 5 or 6 feet in depth, and no brick- $\epsilon$ arth was seen above it. The stratified bed was penetrated by the furrow, and the bedding was disturbed on both sides of it (see Fig. 5). We have, probably, here an example of pebbly and sub-angular gravel and sand, formerly in a frozen condition, in course of being carried down to a lower level until, as in the sections already described, it invaded the channel of the river then flowing at a lower contour.

This furrow deposit is but an example of the occurrence of 
the like deposits on the lower hills to the eastward overlooking the Brent valley. They are described in my papers on the deposits at the Mount, Ealing, etc.* Since they were written, however, other striking instances of the same formation have been observed - a remarkable example being seen in sections exposed during the last three years on Castlebar Hill, I67 0.D. (Fig. 6).

In pits there dug to the depth of about eight feet, the sections showed large masses of contorted, unstratified, very pebbly gravel with included irregular deposits of blue and grey clay and sand, which extended to a lower depth than the face of the pit exhibited; a large deposit of light brown sandy clay much like boulder clay, but with no boulders or chalk in it, though containing large "islands" or patches of gravel streaked with blue

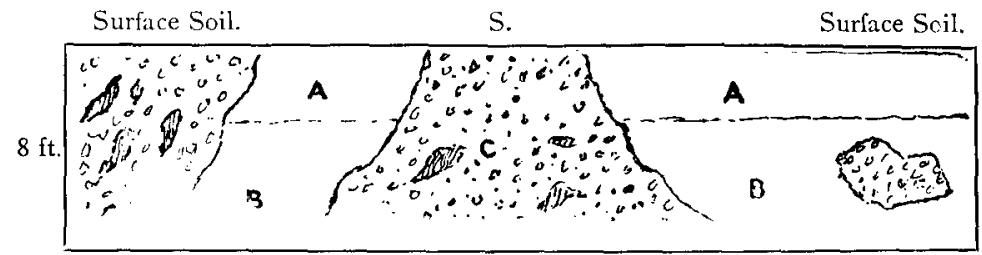

About $40 \mathrm{ft}$.

Fig. 6.-Section at Top of Castlebar Hill, i67 Feet O.D.

A. Light sandy brick-earth.

B. Dark brown brick-earth with enclosures of gravel.

C. Gravel, with enclosures of clay.

silty clay, as in section (Fig. 6). I obtained two small oolitic echinoderms from one of the pits (Echinobrissus?). These deposits extend down the hill to the south, near St. Stephen's Church, to within 560 yards of the known river drift at 130 o.D., with pot holes of gravel between. These irregular deposits have been probably formed by the combined action of ice and river, and may be classed as "Fluvio-Glacial." The following is my analysis of the gravel :-

Black Tertiary pebbles. . . . . . , . I2

Ochreous ditto . . . . . . . . 3 I

Eroded pebbles, i.e, pebbles of which the surface has been in parts "eaten away" by solvents . . . . Io

Ragstone pebbles . . . . . . . . 6

Small quartz pebbles from the size of a pea to that of $\dot{a}$ mustard seed... . . . . . 7

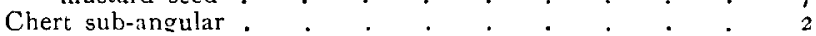

Very small quartzite pebble $\cdot \quad \cdot \quad \cdot \quad \cdot \quad \cdot \quad \cdot \quad \cdot \quad \cdot \quad \cdot \quad \cdot \quad$ I

Soft white pebble. $. \quad . \quad . \quad . \quad . \quad . \quad . \quad$ I

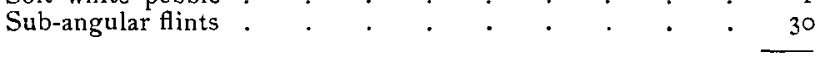

$$
100
$$

* "On probable Glacial Deposits, etc., near Ealing," Proc. Geol. Assoc., vol. viii., p. I73, Palcolithic Man in N.W. Mi.ix., etc. (Macmillan.) 
Dr. Hicks has described such in-filled furrows at Hendon, which he ascribes to the agency of ice, also on Dollis Hill, and in parts of Willesden, and he says that they passed across the valley separating Hendon from Kingsbury-he thinks the implementiferous gravel of the higher horizon should be classed as of contemporaneous age with the "Glacial" deposits at Hendon." When the excavations were made for the tower at Wembley Hill, I noticed similar deposits of gravel, etc., in furrows about five feet deep, penetrating into the London clay beneath, and in another section unstratified gravel divided by brick-earth. The gravel was very pebbly, some of the pebbles being black, of Tertiary age, and others of a dark argillaceous rock, Ragstone and Chert-a small Lima (gigantea?) from the Lias was also found there. The limits of this paper will not allow of my giving all the evidence which points to river drift or "Fluvio-Glacial" drift having once extended above the Brent Valley, since denuded by the action of the Brent and of other small streams, and of the ancient Thames having once flowed there, perbaps as an arm or broad of the main stream. It is sufficient to say that drifts mantle the minor hills north of Ealing, as at Harlesden, where there is brick-earth and a little gravel, at Willesden (where I saw a capping from 20 to 23 feet thick of very sandy loam), and also near the entrance to Twyford Abbey (about I 27 O.D.), where there was an exposure of mottled sandy loam. There is much to be said in favour of such an occurrence, which would unite the gravels descending the hill from Hillingdon, and give a more northern limit to the river drift at Hayes, Southall, and eastward to beyond Ealing.

This suggestion becomes the more probable from the fact that tusks and parts of the jaw and teeth of hippopotamus and other bones were discovered three or four years ago, embedded in a thin stratum of clayey gravel, in making the excavation for the station at Wembley Park; they were found $\mathbf{2} 2$ feet from the surface, and an entire tusk of hippopotamus, 15 inches long, stood out in the clay. These fossils were seen and determined by Messrs. E. T. Newton and Woodward.

\section{IVER (Bucks).}

Returning to the west beyond West Drayton, there are large gravel pits on the banks of the "New Cut," a branch of the Grand Junction Canal, which forms the main stream near Yewsley, in which many flint instruments have been discovered, but the most interesting excavations are those belonging to the Great Western Railway Company, about a mile east of Langley Station, in the parish of Iver ; the drift is here often 25 feet in thickness, and is very remarkable in structure and composition. The section is a long one, and shows contorted and disturbed gravel, etc., above stratified beds. The latter, however, sometimes reach to within

* Quart. Journ. Geol. Soc, vol. xlvii (1891), p. 575 . 


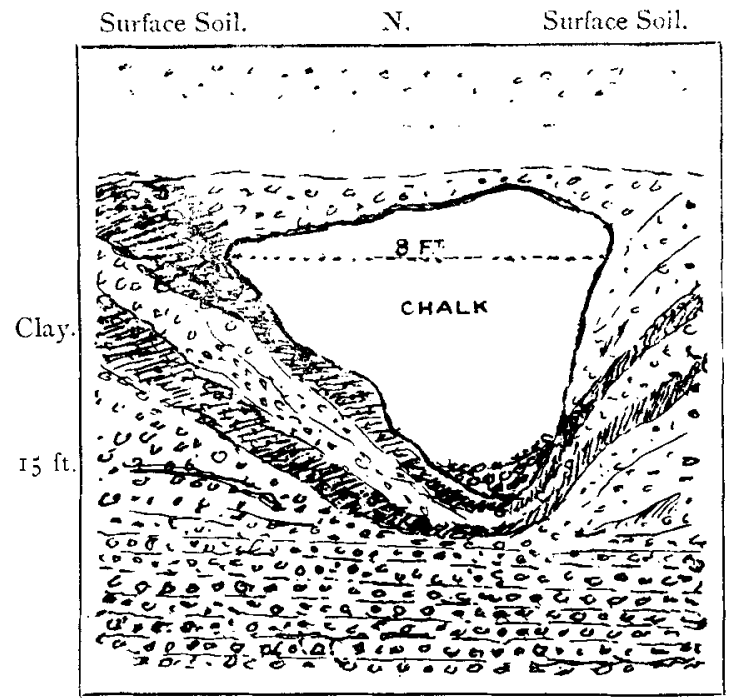

Fig. 7.-IVer Pit, Great Western Railway: Section ShowiNis a Mass of Chalk in Gravel, anil Clay.
Surface Soil.
$\mathrm{N}$.
Surface Soil.

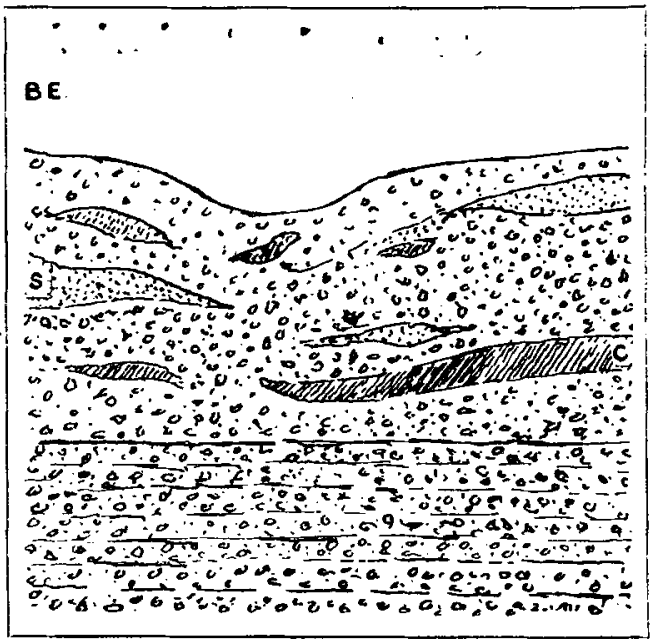

Fig. 8.-IVer Pit, Great Western Raitway.

BE. Brick-earth.

S. Sand.

C. Clay.

Teeth etc., of Elephas were found in the unstratifed drift above the bedied gravel. 
6 or 7 feet of the surface, and from that level in section I obtained a series of the long, sharp, flake-formed late Palæolithic spear-heads and other implements like those already alluded to as being found at West Drayton and Dawley, and as probably corresponding in age with the "working" site at Acton.

But the most interesting discovery in these pits is that of large masses of chalk partly disintegrated, after their deposition in deep furrows, associated with sand and bluish clay in a confused mass; the jagged outline of the blocks of chalk are always distinctly visible, and they have evidently been brought there en masse. I have visited these pits for years, and made sections, from which I select one for description.

The section (Fig. 7) is of the northern face of the pit, and is I 5 feet in depth; it shows an irregular furrow, at the bottom of which is a pocket of clayey gravel, and above it is a large mass of chalk, enclosed with light sand, clay, and gravel (specimens of which were shown at the meeting) surmounting which is brickearth with scattered stones; around the sides and base of the furrow are seams of brown clay and sandy gravel, twisted in a remarkable manner, but still following the roughly triangular outline of the nucleus of chalk, etc., in the centre. The chalk deposit was nearly 8 feet wide at the broadest part, and 6 feet from top to bottom, and the extreme width of the furrow, or in-filled depression, was 13 feet; it penetrates nearly to the base of the section, which is here 15 feet from the surface. The stratified gravels are horizontally bedded below the furrow, but are contorted at the sides of it. The brick-earth and trail above had not been disturbed, and rested on the jagged surface of the chalk.

There have been several such furrows discovered in these excavations, two of which also contained masses of chalk, or chalk rubble; others were filled with clay of varied colour, sand, and gravel. In one of the latter (Fig. 8) a tooth and fragments of the tusks of the mammoth were discovered; this furrow, or channel, was described to me by the labourers as a long one, reaching northwards, and deepening in that direction to 12 feet. The remains appear to have been swept from the surface, and carried into the old river bed by the same agency which transported the chalk and other material.

A large number of the older forms of flint implements have been found in the lower or stratified bed, two of which now in my collection are nearly 8 inches in length; they were generally found at from 15 to 18 feet from the surface.

In my paper on the "Continuity of the Palæolithic and Neolithic Periods," I proposed a new classification of the Stone Age, i.e., its division into "Eolithic, Palæolithic, Mesolithic, and Neolithic." It may be here mentioned that a splendid specimen of the Mesolithic type was discovered in the brick-earth at Iver. 
I was informed by the man who found it, that it was met with at 4 feet from the surface. It is a finely-chipped, double-bladed axe, nearly $8 \frac{\hat{s}}{4}$ inches in length by 4 inches in width, and quite unaloraded. The brick-earth throughout the districts under review is not of a homogeneous character, and it varies in thicknessin some excavations the underlying gravel even reaches the surface. There appears to be at least two kinds of deposit which are included in that term in the higher level river Drift besides "trail," which is common to both; these are a very dense brown clay and a sandy-yellow mottled loam. The latter is almost always found on the upper slopes of the hills overlooking the Brent, Colne, etc. ; it is often mistaken for sandy London clay. The brown clay often contains depressions filled with sandy white loam, almost, in appearance, like a residuum of chalk.

\section{Conclusions.}

The Thames basin, in which the valley of the Thames is formed, is, in the portion under investigation in this paper, bordered to the north by hills rising to over 380 feet and isolated hills of much lesser elevation intervene between them and the 'Thames. There is, in fact, a general incline in the basin towards the river, and that general slope existed in early Quaternary times. There is no real barrier between the higher and lower ground, although there are undulations and lower hills, some of which appear to have escaped glaciation (Harrow, etc.), and also erosion to the extent which the present valleys manifest.

Some of the hills on the borders of the Thames basin are mantled with Glacial deposits (chalky boulder clay) as at Finchley, etc. The bigher slopes of others are clothed with sub-angular and pebbly gravel, and should, in part, be referred to later stages of the ice age, while some of the highest elevations are capped by beds much older than either of these drifts, and appear to have escaped glaciation, using the word in its ordinary sense. All these facts must be taken into account in considering the glacial conditions which have once prevailed in the valley of the Thames and the relation of man thereto as an inhabitant of the valley. In the boulder clay of Middlesex and Essex (now that the old hypothesis of its deposition by icebergs is generally and very properly discarded) we have a veritable moraine formed beneath an ice-front, the extension of which was once far beyond the southern limits of the deposits as now found. When the ice-front retreated, sub-glacial conditions must have for a long period prevailed in the basin of the Thames, and the result would be many of the drifts described in this paper which mark the later and minor stages of glaciation.

As the ice-front of the chalky boulder clays receded-ice 
action in some form, river and flood waters issuing very often from the retreating ice, would be the most important factors in the removal of vast quantities of matter to lower ground until they reached the bed of the river, then flowing at a very high level. Ice must, however, have played a very important part in the erosion of the valley and in the accumulation of drifts at this time. Many of these gravels reaching to the 200 foot contour and perhaps beyond that level, must be regarded, in my opinion, as terrace deposits formed under such conditions. The so-called Glacial drifts extend, as we have seen, to a lower level than what has been considered as river drift and they are alike in structure and composition, and so may also be regarded as FluvioGlacial. Mr. Whitaker says, "Some of these lower spreads of "Glacial ' gravel may be only very high terrace gravel."

During the successive bouts of sub-glaciation to which the Thames basin has been subjected since the deposition of the chalky boulder clay the accumulation of sub-angular and pebbly gravel and clays has been formed and transported by a modified or minor form of ice-sheet or névé to lower and still lower ground. Passing through the valleys, but leaving the higher hills of Harrow, Horsingdon, etc., uncovered, it was often eventually carried bodily, as frozen gravel gathered up in transit, into the river. Such deposits may, therefore, be regarded as a lesser form of moraine matter swept up as the névé slipped over the surface of the land, depositing it often along the banks of the river as terrace deposits. No doubt, such removals of gravel, etc., would be aided by flood streams in summer and as the subglacial conditions gradually relaxed.

It is not, however, suggested that the ice-cap, or névé, was of any great thickness, or such as is at all comparable with the confluent glacier ice, which was, probably, once spread over the midland counties, or with the tongue-like glacier ice, which left us the chalky boulder clay, with its far-travelled erratics. Looking to the general incline of the basin of the Thames towards the river, an ice-cap of comparatively small thickness would be sufficient for the purpose, and, as the unstratified gravels and furrows very rarely contain rocks foreign to the valley, but consist of subangular and pebbly gravel, sand, and clay, it is evident this minor glaciation was of a local character, and, probably, chiefly confined to the Thames basin. The bleached patina of the gravel which is often noticeable, indicates that it had been exposed to atmospheric conditions as a land surface, and the variability of the deposit-i.e., a mass of gravel composed almost entirely of pebbles, and near to it a gathering of white, sub-angrlar flints (deposits of very different gravels) shows very distinctly there were different sources of supply.

In this paper I have not referred to the origin of what I believe to be the older formation, the stratified, jmplentiferous drift 
beneath the unstratified deposits. Whether these beds were laid down by the river flowing through older glacial beds than those chiefly alluded to here, or whether the deposition of the older river drift, with its erratics, proceeded synchronously with the accumulation of the glacial drift, as I have endeavoured to show was the case with the deposits of the later series of fluvio-giacial drift, it would be impossible with our present knowledge to determine ; but it is my conviction, based upon the discovery of implements of plateau type, and looking to the almost obliterated surface of many of the implements found in high-level gravel, and other facts, man must have lived in the Thames valley at that earlier period associated with extreme glacial conditions of climate. The bouts of glaciation since that time, no doubt, varied in intensity, and the later stages of the phenomena lasted a long time.

On the whole, whether man will be proved to have lived before the great ice-age set in or not, he was at least contemporary with the last stages of the glacial period in the valley of the Thames. 